\title{
APPLICATION OF GARDENING PROJECT IN KINDERGARTEN
}

Riska Puspaningrum, Anayanti Rahmawati, Nurul Kusuma Dewi

Universitas Sebelas Maret

riskapuspa8@gmail.com

\section{Article History}

accepted 09/07/2018

approved 01/08/2018

published 17/09/2018

Keywords

gardening project, kindergarten, children

aged 5-6 years

\begin{abstract}
The purpose of this research is to apply gardening project method in Kindergarten. Approach to the research using qualitative. Data collection techniques used are observation, interview, and documentation. The technique of testing the validity of data using triangulation is triangulation of sources and technical triangulation. Data analysis technique used is interactive data analysis model. The results explained that the use of gardening project method can be applied in Kindergarten.Them stages of the implementation of the gardening project include: (1) preparatory stage of preparing teaching materials, tools and materials to be used in project activities. (2) Implementation stage is done after the child understands the tasks assigned by the teacher to each group (3) The closing stage has a role as a reinforcing stage in the project activity, ie the child can present the completed project results. Another friend can give an opinion about the work presented and give rewards.
\end{abstract}

Social, Humanities, and Education Studies (SHEs): Conference Series https://jurnal.uns.ac.id/shes

p-ISSN 2620-9284 e-ISSN 2620-9292 


\section{PENDAHULUAN}

Masa anak usia dini memiliki peran penting dalam masa tumbuh kembang dalam dirinya. Artinya terhambatnya pertumbuhan dan perkembangan pada masa usia dini maka dapat mengakibatkan terlambatnya pada masa selanjutnya. Stimulus yang tepat dapat diberikan anak untuk meminimalisir kemungkinan terjadinya keterlambatan dalam pertumbuhan dan perkembangan anak.

Anak memerlukan rangsangan yang tepat untuk mencapai kematangan yang sangat mempengaruhi keberhasilan pada masa berikutnya (Dirjen PAUDNI (2009). Pemberian rangsangan dan stimulus anak didapatkan pada pendidikan anak usia dini yang dilakukan pada sekolah formal maupun informal. Bentuk penyelenggaraan pendidikan yang menitik beratkan pada peletakan dasar kecerdasan yang meliputi daya pikir, daya cipta, kecerdasan emosi maupun spiritual dapat diartikan sebagai pendidikan anak usia dini (Maimunah, 2012). Pendidikan anak usia dini dapat memberikan stimulus untuk mengembangkan kecerdasan yang dimiliki oleh anak. Peletakan dasar yang meliputi berbagai sifat anak dapat diperoleh pada pendidikan anak usia dini.

Hasil pengamatan awal penerapan metode gardening project dapat menjadi alternatif untuk menstimulasi aspek perkembangan anak, karena anak akan berhubungan langsung dengan tanaman dalam mengerjakan proyek sehingga dapat mengamati secara langsung bagaimana tahapan membuat proyek.

Rumusan masalah dalam penelitian ini adalah apakah penggunaan metode gardening project dapat diterapkan di Taman Kanak-kanak.

\section{Metode Gardening Project}

Gardening project merupakan kegiatan yang melibatkan alam dapat berupa menanam, mewarat dan menghasilkan manfaat yang dapat di ambil dari alam (Michaelis, 2010). Kegiatan dapat dikemas di luar ruangan dengan memanfaatkan alam disekitar untuk menghasilkan suatu karya maupun produk dari alam. Blair (2009) menyatakan bahwa gardening project merupakan kegiatan berkebun yang dapat dilakukan sendiri maupun dengan beberapa orang secara berkelompok untuk menghasilkan suatu produk yang dapat dimanfaatkan dan diperlihatkan hasil dari produk tersebut.

Beberapa manfaat yang dapat diambil pada kegiatan gardening project seperti mengenalkan anak untuk sadar lingkungan, menambah pemahaman pada anak mengenai berbagai jenis tanaman maupun hewan yang ada disekelilingnya. Secara khusus Departement of Horticulture Cornell University dalam Rochman (2009) menjelaskan bahwa selain meningkatkan pemahaman mengenai jenis tanaman dan hewan, juga mampu menumbuhkan kepedulian terhadap lingkungan alam disekitar anak. Metode gardening project dapat dijadikan upaya untuk memberikan pengaruh pada kecerdasan naturalis pada anak usia dini. Manfaat yang terdapat pada metode gardening project dapat digunakan untuk menstimulus kecerdasan naturalis anak yang berkaitan dengan pemahaman dan karakteristik mengenai tumbuhan.

Tahap-tahap small project yang digunakan untuk melakukan metode gardening project menurut Masitoh (2005) meliputi: (1) Tahap persiapan, terdiri dari pengantar dimana guru memberikan kegiatan apersepsi yaitu memberi tanya jawab pada anak mengenai materi yang akan diberikan. Apersepsi dapat bertujuan untuk memberikan gambaran pada anak materi yang akan dipelajar. Selanjutnya guru memberikan pengarahan terhadap cara kerja kegiatan gardening project. Pengerjaan proyek dapat dilakukan dengan berkelompok dan secara individu. Ketika pengerjaan kelompok, guru dapat mengorganisasikan kelompok kerja dan memberikan penjelasan mengenai tugas yang harus dikerjakan anak pada setiap kelompok, (2) Tahap pelaksanaan terdiri dari tahap bekerja dan hasil, dimana anak dapat melakukan kegiatan gardening setelah mendapat pengarahan dari guru. Anak dibebaskan untuk berkreasi dalam mengerjakan proyek, dan (3) Tahap evaluasi yaitu hasil proyek yang telah dibuat anak 
dapat dilakukan presentasi untuk menampilkan hasil karyanya. Hal ini bertujuan untuk memberi penguatan anak mengenai materi yang disampaikan.

\section{METODE}

Penelitian ini dilaksanakan di TK Widya Putra Karanganyar yang berlangsung selama 7 bulan yaitu bulan Januari 2018 hingga bulan Juli 2018. Subjek penelitian ini adalah anak usia 5-6 tahun. Pendekatan penelitian ini menggunakan pendekatan kualitatif. Data penelitian yang dikumpulkan berupa penerapan metode gardening project di Taman Kanak-kanak. Sumber data primer yaitu anak dan guru. Sumber data sekunder yaitu RPPH, catatan lapangan, bahan ajar dan skenario pembelajaran. Teknik pengumpulan data kualitatif menggunakan teknik observasi, wawancara, dan dokumentasi. Uji validitas data kualitatif penelitian ini menggunakan triangulasi sumber dan triangulasi teknik. Analisis data menggunakan analisis interaktif yang terdiri dari 4 tahap yaitu pengumpulan data, reduksi data, penyajian data dan penarikan kesimpulan.

\section{HASIL DAN PEMBAHASAN}

Pelaksanaan penelitian terdiri dari perencanaan, pelaksanaan, pengamatan dan refleksi. Data wawancara, observasi dan dokumentasi dianalisis mengacu pada pelaksanaan penerapan metode gardening project di Taman Kanak-kanak.

\section{Kegiatan Proyek}

Proses pengerjaan proyek dapat menjadikan anak paham dan mendapat pengalaman langsung untuk mengamati tanaman mulai dari jenis maupun karakteristik dari tanaman yang sedang ditanamnya. Kegiatan proyek berkebun dapat diterapkan dalam pembelajaran di Taman Kanak-kanak dengan menggunakan berbagai media tanam dalam proyek berkebun. Agar anak mendapat manfaat untuk lebih peduli terhadap tanaman yang ditanam sendiri. Hal tersebut sejalan dengan pendapat Herdianing (2014) mengungkapkan bahwa kegiatan berkebun dapat dijadikan sarana untuk bermain yang dapat mengembangkan aspek perkembangan anak serta memupuk rasa tanggung jawab dan melatih kesabaran.

Pelaksanaan proyek dapat dilakukan anak dengan bekerja secara berkelompok, dimana setiap kelompok terdiri dari dua anak yang memiliki tugas masing-masing. Awalnya anak memiliki kesulitan dalam mengerjakan secara kelompok, karena mereka terbiasa bekerja secara individu. Setelah dilakukan penerapan metode gardening project, anak mulai menunjukkan perkembangannya dalam bekerja secara kelompok.

Proses pembelajaran yang dilakukan peneliti mendapatkan temuan bahwa anak mengalami peningkatan dalam proses pengerjaan gardening project, anak mulai terbiasa dengan metode pembelajaran gardening project. Manfaat lain kemampuan anak dalam berkebun juga dapat berkembang mulai dari cara menanam, merawat tanaman maupun mengidentifikasi jenis dan karakeristik tanaman

Metode gardening project dapat memberikan pengalaman langsung pada anak, sehingga materi ajar yang diberikan guru dapat diamati secara langsung oleh anak. Proyek bertanam menjadi salah satu cara yang cukup optimal untuk diterapkan dalam pembelajaran di taman kanak-kanak. Terlihat pada pelaksanaan metode gardening project bahwa anak sangat antusias dalam melaksanakan kegiatan proyek. Kegiatan pembelajaran yang dilaksanakan didalam dan di luar kelas menjadi lebih menarik dan variatif. Sehingga anak tidak bosan dengan metode pembelajaran yang monoton.

Anak juga menunjukkan kepekaan terhadap lingkungan alam sekolah dengan selalu merawat tanaman yang telah ditanam. Setiap pagi maupun ketika istirahat, anak menyiram tanaman dan merawat tanaman yang berada di sekolah. Sehingga setelah beberapa kali dilakukan dan diberikan penejalasan mengenai kepedulian akan lingkungan alam, anak mampu menerapkannya tanpa disuruh guru. 


\section{Tahapan Metode Gardening Project}

Tahap metode gardening project tidak lepas dari tahap kegiatan proyek yang digunakan untuk melaksanan kegiatan berbasis proyek. Dalam melaksanakan kegiatan proyek bagi anak ada tiga tahap yang harus dilakukan diantaranya menurut masitoh (2005) meliputi:

a. Persiapan

Kegiatan dirancang sesuai dengan kondisi sekolah, dengan memanfaatkan ruang kosong di halaman sekolah maupun ruang kelas. Guru merancang kegiatan yang dapat menarik perhatian anak agar terlihat menarik dan dapat dikerjakan dengan mudah oleh anak, sehingga anak tidak jenuh untuk melaksanakan metode gardening project. Setiap pertemuan tanaman yang digunakan untuk gardening project dapat dibedakan antara pertemuan satu dengan yang lain. Hal ini bertujuan untuk memberikan pengetahuan yang lebih banyak dmengenai berbagai jenis tanaman yang dapat dipelajari anak.

Setelah guru mempersiapkan bahan ajar yang akan digunakan untuk melaksanakan metode gardening project, langkah selanjutnya yaitu melakukan kegiatan belajar mengajar. Guru membuka pembelajaran dengan menerapkan kegiatan pembiasaan yaitu mengucap salam, berdoa, absensi dan melakukan persepsi mengenai materi yang akan disampaikan pada pembelajaran hari itu. Apersepsi terdiri dari guru mengajak anak untuk memikirkan mengenai tanaman dan memberikan tanya jawab mengenai tanaman yang akan digunakan untuk gardening project. Pengorganisasikan cara kerja pada anak dengan kelompok dilaksanakan diawal. Guru memberikan arahan tugas-tugas dari setiap anggota kelompok.

b. Pelaksanaan

Setelah guru menjelasakan tahap mengerjakan proyek diawal, anak dapat bekerja dengan kelompok jika cara pengerjaannya secara kelompok. Setiap kelompok yang terdiri dari dua orang dapat mengambil alat dan bahan yang telah disediakan di depan. Guru memberikan pengarahan mengai tugas dari setiap anak dalam kelompok. Sejalan dengan Ishjoni (2010) mengungkapkan bahwa metode proyek dapat menggerakan minat anak untuk melakukan kerjasama sepenuh hati. Awalnya anak memiliki kesulitan dalam mengerjakan secara kelompok, karena mereka terbiasa bekerja secara individu. Setelah dilakukan pada pertemuan kedua, anak mulai menunjukkan perkembangannya dalam bekerja secara kelompok. Guru bertugas sebagai fasilitator bagi anak ketika mengalami kesulitan dalam mengerjakan proyek.

Hasil proyek yang dibuat dapat ditampilkan dan dipresentasikan di depan kelas. Sehingga setiap anak memiliki kesempatan untuk menjelaskan karya yang telah dikerjakannya. Presentasi juga dapat bertujuan untuk mengingat kembali materi yang diajarkan seperti mengelompokkan jenis dan karakteristik yang dimiliki tanaman pada proyek yang telah dihasilkan. Kemampuan dalam menyampaikan pendapat juga dapat dilatih pada saat presentasi didepan kelas, teman yang lain juga berkesempatan untuk menanyakan dan memberi saran mengenai proyek yang telah dibuat oleh anak atau suatu kelompok.

c. Evaluasi

Kegiatan evaluasi merupakan kegiatan recalling materi yang telah disampaikan dan tujuan dari proyek yang telah dibuat anak. Penguatan diberikan pada anak untuk memahami jenis maupu karakteristik yang terdapat pada tanaman yang telah ditanam pada proyeknya. Anak yang berhasil menyelesaikan proyek mendapat reward sebagai penilaian guru atas kinerjanya. Tahapan yang dilakukan dalam mengerjakan gardening project dapat digunakan sebagai tolak ukur dalam penerapan metode gardening project di Taman Kanak-kanak. Sejalan dengan pendapat Conny Semiawan, dkk. (1992) mengungkapkan bahwa manfaat yang dapat diperoleh dari metode proyek adalah kegiatan belajar menjadi lebih menarik, karena pengetahuan itu bermanfaat bagi anak untuk mengapresiasi lingkungannya, memahami, serta memecahkan 
masalah yang dihadapi dalam kehidupan sehari-hari. Sehingga pada tahap evaluasi anak dapat mengingat kembali bagaimana proses pembuatan proyek dan mendapat pengalaman secara langsung.

Perkembangan yang cukup signifikan dapat dilihat secara nyata setelah dilakukan tindakan dengan menggunakan metode gardening project. Hal ini menunjukkan bahwa dengan metode gardening project dapat diterapkan di Taman Kanak-kanak.

\section{SIMPULAN}

Berdasarkan hasil penelitian dapat disimpulakan bahwa penggunaan metode gardening project dapat diterapkan dalam pembelajaran di Taman Kanak-kanak. Tahapan pelaksanaan metode gardening project diawali dengan kegiatan persiapan yaitu menyiapkan bahan ajar, alat dan bahan yang akan digunakan dalam kegiatan proyek, dan mengorganisasiakan kelompok. Tahap pelaksanaan dilakukan setelah anak memahami tugas-tugas yang diberikan oleh guru pada setiap kelompok. Sehingga anak dapat membuat proyek dengan kelompoknya. Tahap penutup memiliki peran sebagai tahap penguat dalam kegiatan proyek, yaitu anak dapat mempresentasikan hasil proyek yang telah diselesaikan. Teman yang lain dapat memberikan pendapat mengenai hasil karya yang dipresentasikan dan memberikan reward.

Pengerjaan proyek berkelompok mampu memberikan pelatihan anak untuk meningkatkan kemampuan dalam bersosialisasi dan kerjasama dengan teman satu kelompokknya. Sehingga anak terbiasa untuk berinteraksi dan melakukan diskusi dengan orang lain, yaitu teman satu kelompok. Tugas masing-masing anak dalam kelompok juga bermanfaat untuk memberikan tanggungjawab pada anak dalam menyelesaikan tugas yang diberikan. Kepekaan terhadap tanaman dan lingkungan alam disekitar anak juga dapat meningkat, dimana anak dapat melakukan pembiasaan merawat tanaman disetiap harinya.

\section{DAFTAR PUSTAKA}

Cony Semiawan, dkk. (1992). Pendekatan Ketrampilan Proses. Jakarta: PT Gramedia. Cruz, S.(2017). Farm Garden Projects. University of California

Hoerr, T. R., Boggeman, S. \& Wallach, C. (2010). Celebrating Every Learner. Activities and Strategies for Creating a Multiple Intelligences Classroom. Jossey-Bass.

Ishjoni. (2010). Model Pembelajaran Anak Usia Dini. Bandung:Alfabeta.

Maimunah (2012). PAUD (Pendidikan Anak Usia Dini. Jogyakarta: DIVA Pers

Michaelis, A. (2010). Learning Naturally-gardening with children. National Childcare Accreditation Council (NCAC). 18-20

Moeslichatoen. (2004). Metode Pembelajaran di TK. Malang: Departemen Pendidikan dan Kebudayaan Direktorat Jenderal Pendidikan Tinggi Proyek Pendidikan Tenaga Akademik

Musfiroh, T (2008). Pengembagan Kecerdasan Majemuk. Jakarta: Universitas Terbuka.

Railsback, J. (2002). Project Basedinstruction: creating excitement for Learning. Northwest R/egional Educational Laboratory, Oregon 40.

Sujiono, \& Nurani, Y. (2009). Konsep Dasar Pendidikan Anak Usia Dini.Jakarta: PT. Indeks. 